\title{
Gill nets selectivity determine the fish community in connected oxbow lakes of the Pantanal
}

\begin{abstract}
Pantanal is known because of the amplitude on the water dynamics, with a pronounced flood and dry seasons. The water expansion and retraction reflect in the hydric connectivity between river and bays, resembling the environments and causing distinct characteristics of water quality. In order to capture fish in these environments the gill nets are used. These passive devices allow the capture of a certain length category according to the meshes size, avoiding the capture of fish that are too small or too large, characterizing their selectivity. The present study aims to characterize the ichthyofauna of an oxbow lake system, as well as to establish its relationship with the seasonal, limnology and structural alterations of fish, seeking to understand the spatial and temporal distribution characteristics of the community. Three points of two side lakes were sampled using a set of gill nets with $2,3,4$ and $5 \mathrm{~cm}$ between knots, allocated in spatial and temporal distribution characteristics of the community. Three points of two side lakes were sampled using a set of gill nets with $2,3,4$ and $5 \mathrm{~cm}$ between knots, allocated in
parallel columns at every 10 meters in the lakes. The samples were performed during the day and during the night, where the nets were left in the water for 6 hours. Concomitantly to the fish sampling, the limnologic variables were obtained using a portable field equipment and Secchi disk. The results showed that the limnological variables changes according to the hydric seasons. These changes associated to the connectivity between the river and lakes presented an increase in the diversity indices considering the inlet of water in the system, while the disconnected lakes remained about the same during the entire year. This discrepancy may be caused by the selectivity of the gill nets using in the study, where fish may use the flooded area during the high waters, reducing the capture capacity of these devices. In the Pantanal, the connectivity associated to the selectivity of the gill nets determine the fish community.
\end{abstract}

Keywords: Tropical Wetlands; Ichthyology; Sampling Methods.

\section{Seletividade de redes de emalhar determina a comunidade de peixes em meandros abandonados conectados no Pantanal}

\begin{abstract}
O Pantanal é conhecido pela amplitude na dinâmica das águas, com estações de cheia e seca bem acentuadas. A expansão e retração da água refletem na conectividade hídrica entre rios e baías, tornando os ambientes semelhantes e causando características distintas na qualidade da água. Para capturar peixes nesses ambientes, as redes de emalhar são usadas. Esses dispositivos passivos permitem a captura de uma determinada categoria de comprimento de acordo com o tamanho das malhas, evitando a captura de peixes muito pequenos ou muito grandes, caracterizando sua seletividade. 0 presente estudo tem como objetivo caracterizar a ictiofauna de um sistema de meandros abandonados, bem como estabelecer sua relação com as alterações sazonais, limnológicas e estruturais dos peixes, buscando entender as características de distribuição espacial e temporal da comunidade. Três pontos de dois lagos laterais foram amostrados usando um conjunto de redes de emalhar com 2, 3, 4 e $5 \mathrm{~cm}$ entrenós, alocados em colunas paralelas a cada 10 metros nos lagos. As amostras foram realizadas durante o dia e a noite, onde as redes foram deixadas na água por 6 horas. Concomitantemente à amostragem de peixes, as variáveis limnológicas foram obtidas utilizando um equipamento de campo portátil e um disco de Secchi. Os resultados mostraram que as variáveis limnológicas mudam de acordo com as estações hídricas. Essas mudanças associadas à conectividade entre o rio e os lagos apresentaram um aumento nos índices de diversidade considerando a entrada de água no sistema, enquanto os lagos desconectados permaneceram praticamente os mesmos durante todo o ano. Essa discrepância pode ser causada pela seletividade das redes de emalhar utilizadas no estudo, onde os peixes podem usar a área inundada durante as águas altas, reduzindo a capacidade de captura pelos dispositivos. No Pantanal, a conectividade associada à seletividade das redes de emalhar determina a comunidade de peixes.
\end{abstract}

Palavras-chave: Planícies Inundáveis Tropicais; Ictiologia; Métodos de Amostragem.

Topic: Uso de Recursos Naturais

Reviewed anonymously in the process of blind peer.
Received: $10 / 08 / 2019$

Approved: 28/09/2019
Claumir Cesar Muniz (D)

Universidade do Estado de Mato Grosso, Brasil

http://lattes.cnpq.br/2202899559144774

http://orcid.org/0000-0002-2082-2234

claumir@unemat.br

Ernandes Sobreira Oliveira Junior (iD

Universidade do Estado de Mato Grosso, Brasil

http://lattes.cnpq.br/7461346615427709

http://orcid.org/0000-0002-6953-6917

ernandes.sobreira@gmail.com

Ana Paula Dalbem Barbosa

Universidade do Estado de Mato Grosso, Brasil

http://lattes.cnpq.br/4090241675573333

http://orcid.org/0000-0002-6282-4799

pauladalbem11@gmail.com
Alberto Carvalho Peret (D)

Universidade Federal de São Carlos, Brasil http://lattes.cnpq.br/0995579236780271 http://orcid.org/0000-0002-8701-1866

peret@power.ufscar.br
Referencing this:

MUNIZ, C. C.; OLIVEIRA JUNIOR, E. S.; BARBOSA, A. P. D.; PERET, A. C.. Gill nets selectivity determine the fish community in connected oxbow lakes of the Pantanal. Revista Ibero Americana de Ciências Ambientais, v.10, n.5, p.295-306, 2019. DOI: http://doi.org/10.6008/CBPC2179-6858.2019.005.0026 


\section{INTRODUCTION}

Pantanal is known because of the amplitude on the water dynamics, with a pronounced flood and dry seasons (JUNK et al., 1989), expanding the water more than five times during the high waters (MORAES et al., 2013). The flooded area and its duration indicate more availability of habitats for the ecosystem services (TALBOT et al., 2018), affecting the abundance and richness of fish (BONETTO et al., 1981; ESCALERAVÁSQUEZ et al., 2017). The water expansion and retraction reflect in the hydric connectivity between river and bays, resembling the environments (THOMAZ et al., 2007). As a similar environment, fewer barriers are found for fish lateral migration. For instance, the organic matter provided during the high waters favours the invertebrates mass production, a propitious moment for fish feeding in the flooded areas (ALHO, 2008).

The connectivity also impacts the biodiversity of fish due to the drift of eggs and larvae of longdistance migratory fish deposited in the river chain directed to the side bays, which are shallower and offer shelter and food (VAZZOLER, 1996). Moreover, the connectivity provides a more complex fish community structure than during the low waters (SILVA et al., 2010; TAKAHASHI et al., 2013). These differences in the seasons and connectivity to the main river channel causes distinct characteristics of water quality (JUNK et al., 1989), which are also found as a factor ruling the fish community, pressing for adaptations, or excluding species that do not respond to the changes (COSTA et al., 2015; FERNÁNDEZ-OSUNA et al., 2016). For instance, during the raising waters, low dissolved oxygen is found because of the biochemical processes in the organic compounds in the sediment (ABDO et al., 2004). This deficiency in oxygen concentration causes morphological adaptations on Characidae fish, which raise the labial surface to take oxygen in the beyond between the water and atmosphere (WINEMILLER, 1989). Other characteristics, such as temperature, precipitation, nutrient availability are also important factors influencing fish community composition in freshwaters (ESTEVES, 2011).

The changes in the environment are highly seen in the side lakes, which are more susceptible to the changes due to the shallower morphometry and flatter than the main channel (WANTZEN et al., 2008). In these systems, the river deposit the nutrients during the raising waters, but take them out during the ebb (JUNK et al., 1989). The morphometry also determines a propitious environment to the macrophytes proliferation, where the nutrients provided by the movement of the water, together to the shallow depth, favour the abundance and richness of these species (POTT et al., 2011), configuring spatial heterogeneity. Due to the spatial heterogeneity in the side lakes, generally, the richness and abundance of fish are higher than in the river (GLINSKA-LEWCZUK et al., 2016), feeding the riverine system and sustaining the trophic and fishing activities in the basin (CARVALHO et al., 2005). Moreover, the availability of food and shelter favour the dissemination of small fish, accreting the biodiversity.

To identify the fish community composition, gill nets are commonly used worldwide from the tropics to the pole (HOVGÅRD et al., 2000). These devices are passive and allow the capture of a certain length category according to the meshes size, avoiding the capture of fish that are too small or too large, which characterizes their selectivity (SPARRE et al., 1997). However, in the Pantanal, sampling species must be 
monitored frequently, and the nets should not be left for a long time because of the threat of 'piranhas' and Caiman attacks, and repairs or replacement of nets are constantly carried out. Therefore, hereby we used the gill nets to identify the fish community in the Pantanal side bays, connected and disconnected to the Paraguay river depending on the hydric season. We believe that (1) the fish community in the side lakes of the Pantanal will respond to the water quality changes according to the hydric season; (2) the connectivity of the side lakes to the Paraguay river will affect the similarity in the composition of fish, mainly in the lakes disconnected during the low waters. Thus, the present study aims to characterize the ichthyofauna of an oxbow lake system, as well as to establish its relationship with the seasonal, limnology and structural alterations of fish, seeking to understand the spatial and temporal distribution characteristics of the community.

\section{MATERIALS AND METHODS}

The specimens were sampled between September 2005 and September 2007, every two months, in the Caiçara's oxbow lakes (160 4' - 16 7' S and 570 46' - 57ㅇ 44' W) next to the municipality of Cáceres, in the Northern Pantanal. A system of two side lakes from the Paraguay river, where one is connected to the river during the whole year (here called Lower Baía Caiçara- $L B C$ ), and the other connected to the UBC and to the river only during the high waters (here called Upper Baía Caiçara - UBC; Figure 1).

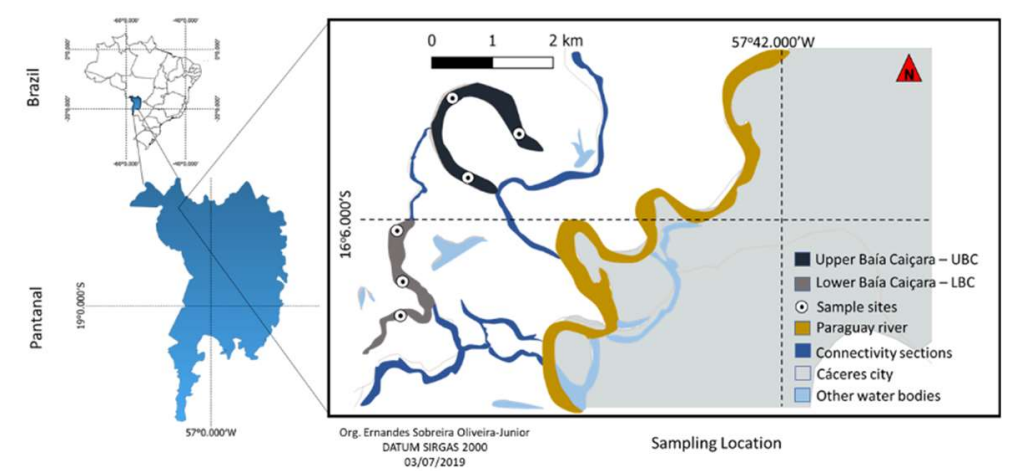

Figure 1: Study area and collection points. Caiçara's lakes system. UBC = Upper Baía Caiçara; LBC = Lower Baía Caiçara. Northern Pantanal. Cáceres, MT.

The samples were obtained from three points of each system using a set of gill nets with 2, 3, 4 and $5 \mathrm{~cm}$ between knots. Each net measured 35 meters length by 2 meters height, allocated in parallel columns at every 10 meters in the lakes. The samples were performed during the day and during the night, where the nets were left in the water for 6 hours. Concomitantly to the fish sampling, the following limnologic variables were obtained: dissolved oxygen $(\mathrm{mg} / \mathrm{l}), \mathrm{pH}$, electrical conductivity $\left(\mu \mathrm{S} . \mathrm{cm}^{-1}\right)$, water transparency $(\mathrm{cm})$, water temperature $\left({ }^{\circ} \mathrm{C}\right)$ and water depth $(\mathrm{cm})$ using a portable field equipment (HACH multi HD 40D) and Secchi disk.

After the capture of the fish, the specimens were split by sampling point, season and gill net, and enclosed in thermal insulation boxes containing $4 \%$ of formalin solution. The specimens were identified using Britski et al. (1999), and the biometric data were taken. The Shannon-Wiener Diversity Indexes ( $\left.H^{\prime}\right)$ and Equitability ( $\left.E^{\prime}\right)$ were calculated to demonstrate the ichthyofauna community according to the seasons and 
to the site (LBC and UBC).

The Holt method (1963) was used for the calculation of selectivity and to estimate the available species in the environment, through which the distribution of the available frequency of individuals per size class was obtained. The selectivity factor of the gill nets is given by: $\mathrm{FS}=(-2 a) /(b(\mathrm{ma}+\mathrm{mb}))$, where: ' $F S^{\prime}$ is the selectivity factor; ' $a$ ' and ' $b$ ' are given by the linear regression; ' $m a$ ' is the smaller net size; and ' $m b$ ' is the bigger net size. Afterwards, the estimated selectivity is calculated by the followed expression: SI = Exp [$\left.0,5^{*}\left((\lambda-k)^{2} / s^{2}\right)\right]$, where: 'Sl' is the Selectivity of the class of size; ' $\lambda$ ' is the trasformed size (class of fish size/net size); ' $k$ ' is the selectivity factor; ' $s$ ' is the standard deviation; and 'In' is the natural logarithm.

Only the species occurring in the four periods were considered to be correlated to the water variables, connectivity and seasons. The environments were compared for physicochemical data using hierarchical agglomerative clustering, and the similarities between the sites and sampling periods were established. Canonical correspondence analysis (CCA) was also used to establish the relationships between the environmental variables, the available species and the sampling periods. These analyses were performed with the use of version 2009.3.01 of XLSTAT program.

\section{RESULTS}

Fish community composition
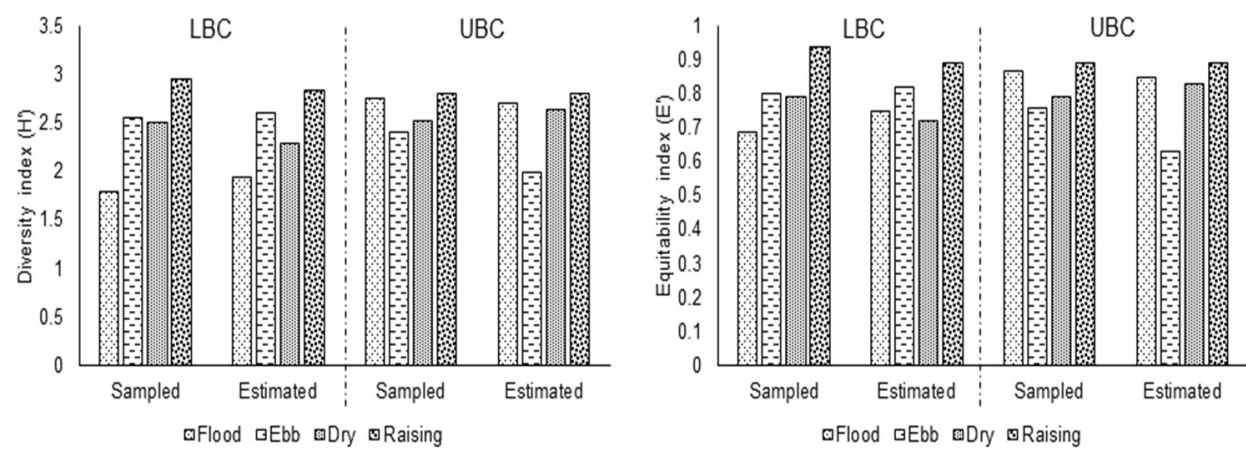

Figure 2: Values of diversity $\left(\mathrm{H}^{\prime}\right)$ and Equitability ( $\mathrm{E}^{\prime}$ ) indices obtained in the Caiçara oxbow lake system (LBC and UBC), in the Pantanal considering the four hydric seasons from September 2005 to September 2007.

In total, 5,051 specimens were collected using the gill nets throughout the two years. These specimens were distributed into 96 species. The Diversity Index values varied from 1.40 to 2.8 in UBC, and from 1.80 to 2.96 in LBC, without significant difference between the sites. However, in the LBC lower indices values were found during the flood, increasing during the ebb and dry. The highest value of the diversity index in this site was found during the raising waters. In the UBC, the ebb and the dry period presented the lowest diversity indices values and the highest during the raising waters. Interestingly to add that no relationship was found between the indices in the analyzed sample sites $\left(R^{2}=0.03\right)$, indicating that the increase of values in one site does not represent the increase in the other. Three species (Acestrorhynchus pantaneiro Menezes (1992), Plagioscion ternetzi (BOULENGER, 1895) and Pygocentrus nattereri Kner (1858) represented more than $76 \%$ of the total species sampled in the ebb period, which led to a significant decrease 
of the Equitability values (0.63). In the dry period, the referred species accounted for less than $50 \%$ of the total species sampled, with the Equitability being close to 0.90 (Figure 2). Considering the Holt method to estimate the richness and abundance of the individuals sampled in the sites, we found that for LBC values of the diversity index was lower during the flood and ebb, and higher for dry and raising waters, contrasting the values for UBC, where the dry and raising waters presented higher diversity values. The same was observed for the Equitability index.

\section{Gill nets selectivity}

To perform the analysis of selectivity and comparisons of the environment characteristics determining the species composition, only 2,100 individuals were considered because were the species sampled in all the four hydric seasons. These individuals were distributed in 3 orders, 7 families and 9 species, as follows: A. pantaneiro; P. nattereri; Potamorhina squamoralevis (BRAGA et al., 1983); Psectrogaster curviventris Eigenmann et al. (1903); Hemiodus orthonops Eigenmann et al. (1903); Pachyurus bonariensis Steindachner (1879); Plagioscion ternetzi (BOULENGER, 1895); Liposarcus anisitsi Eigenmann et al. (1903); Pimelodus maculatus La Cépède (1803).

Considering the frequency of the species that occurred during the all four hydric seasons, $A$. pantaneiro (39.88\%) was the most representative species, except for the flood period (1.82\%), followed by P. nattereri (39.11\%) in both environments. $P$. squamoralevis, $P$. curviventris and $L$. anisitsi were not collected at the LBC during the flood period, although $H$. orthonops and $P$. nattereri (both accounting for $25.45 \%$ ) and L. anisitsi (18.18\%) were found to be the most representative species of the composition of the ichthyofauna sampled in the flood period in the UBC.

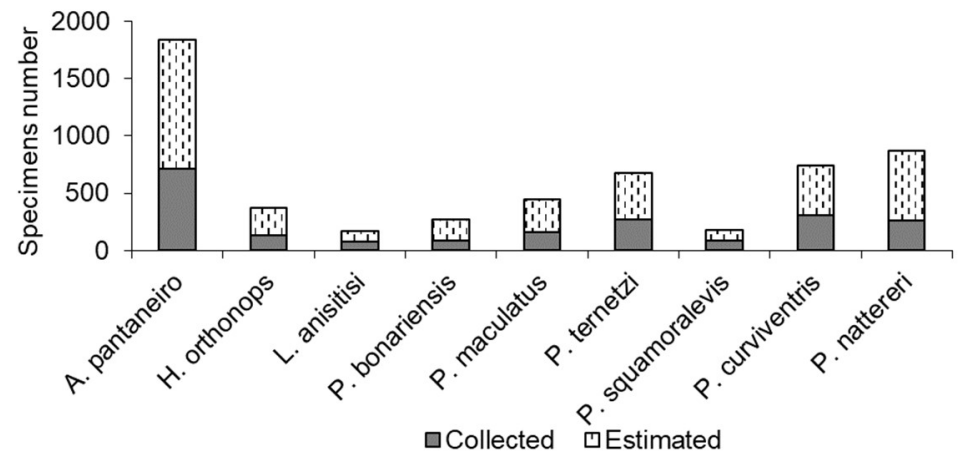

Figure 3: Holt estimated values and collected number of the species sampled in Caiçara oxbow lakes, September 2005 to September 2007.

Due to the selectivity of the gill nets, our results showed that only $35 \%$ of the species available in the system were sampled, where instead 2,100 individuals sampled, 3,449 specimens in both environments were estimated. This value represents an increment of approximately $65 \%$ of the available specimens in the Pantanal oxbow lakes studied. In the UBC, the environment that disconnects the water flow from the Paraguay river, the increment was only $10 \%$, and in the $L B C$, the lake always connected the to Paraguay river, the increment of specimens was more than $200 \%$ (Figure 3). 


\section{Environment relation to the fish community}

The variation of the Paraguay river water level characterized the flood pulse of the Pantanal. The flood peaks occurred in February and March, and the driest months were August and September. For the period of data sampling, the highest water level was 5.38 meters, in April 2006, and the lowest one was 1.03 meters, in September 2005 (Figure 4).

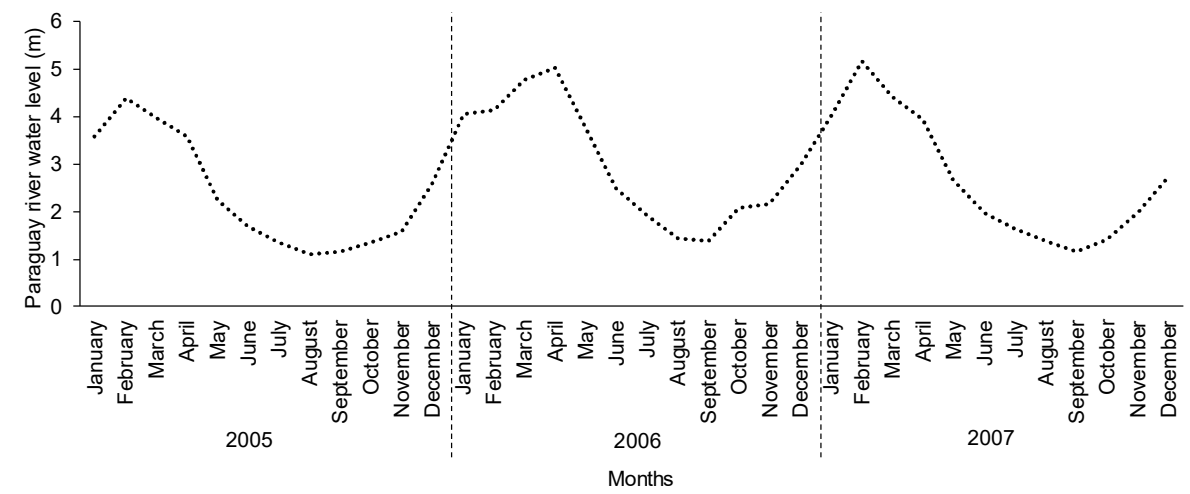

Figure 4: Water level of the Paraguay river during the period of September/2005 to September/2007. Data from the Brazilian Navy - Sinalização Náutica do Oeste. Accessed on 18 September 2008.

Using hierarchical agglomerative clustering, and based on physic-chemical data, the sampling environments were related to the seasonal periods. The Figure 5 shows the formation of 3 well-distinguished groups, with the first group being formed by the flood and ebb seasons, considered as intermediate periods between the other periods. The group II is formed by the raising water season and the group III is formed by the dry season. Sorensen's similarity index was above 0.95 in all the periods between the environments and seasons, with ebb and flood being the most similar periods, close to 1.0. Thus, the seasonal variation showed a direct influence on the composition of the fish community structure in the oxbow lakes studied. Both, the seasonal periods and the environments were paired, showing a high similarity between the UBC and LBC, considering the limnology characteristics.

The Canonical Correspondence Analysis (CCA) was performed in both environments, considering the sampling sites (UBC and LBC), the limnology and the 9 species considered in the study). In the UBC (Figure 6), during the flood period, the high transparency and depth reduced the distribution of detritivore species and other species that feed on the substrate. L. anisitsi and P. squamoralevis, illiophagous species, were abundant in the flood, as well as $P$. bonariensis, Sciaenidae. These species present a modified mouth that points downwards to capture crustaceans and invertebrate larvae in the substrate. These species were sampled in the deepest areas, and visual acuity is the most important feature of the third species mentioned.

In the flood period, after the stabilization of the system, the values of water transparency were the highest up to system coalescence, at the beginning of ebb period. The highest transparency values for UBC were obtained in March $2007(160 \pm 23 \mathrm{~cm})$. The maximum depth of the system was obtained in January $2006(620 \pm 104 \mathrm{~cm})$. 


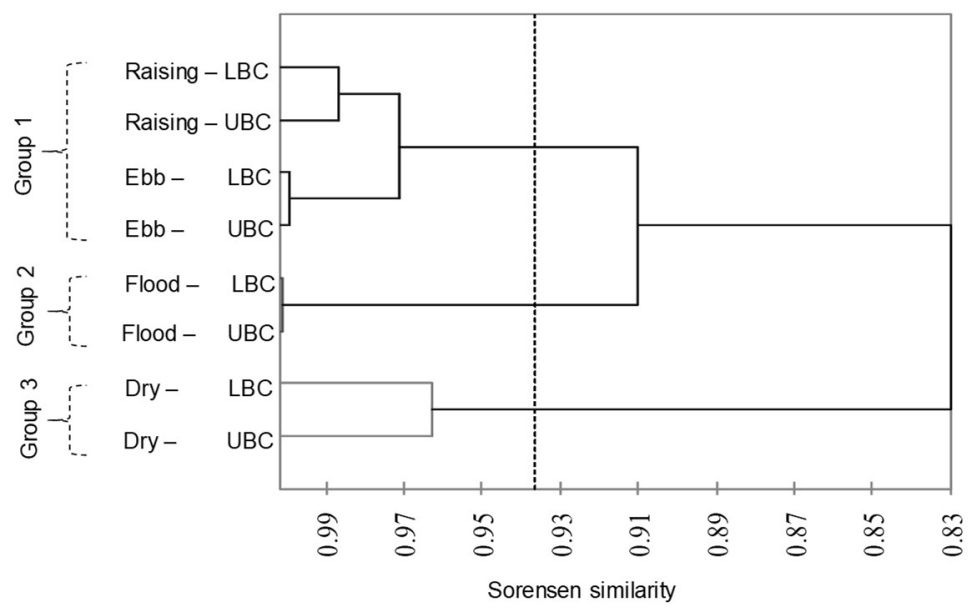

Figure 5: Hierarchical agglomerative clustering comprising limnological data of the Caiçara oxbow lakes system showing the seasons from September 2005 to September 2007.

In the dry period, which occurs from October to December, the temperature $\left(29.72 \pm 1.54{ }^{\circ} \mathrm{C}\right)$ and conductivity $\left(64 \pm 17 \mu \mathrm{S}^{s-1}\right)$ increased the abundance of $P$. curviventris and $P$. maculatus. These two species were the most abundant in the referred period, accounting for 132 and 78 specimens, respectively. The $P$. curviventris species, detritivore, was the most favoured by the sediment inflow in the oxbow lakes, as well as P. maculatus, omnivorous, which was favoured by the increment of insects and items from riparian forests, for instance.

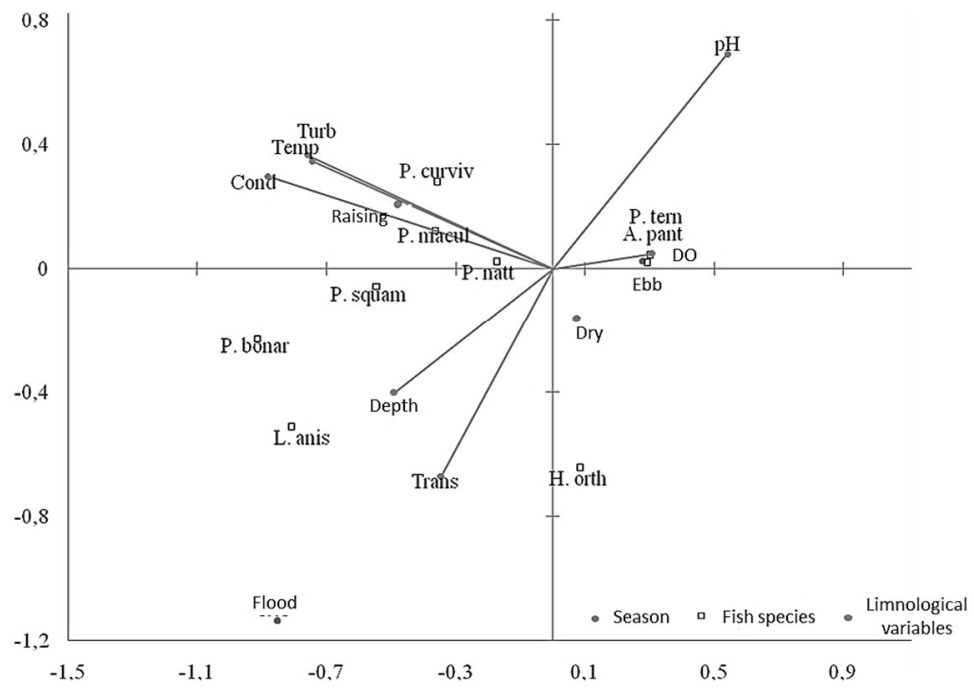

Figure 6: Canonical correspondence analysis (F1 and F2 $=88.74 \%$ ) of the environmental variables, collected species and sampling sites of the Upper Caiçara oxbow lake (UBC) from September 2005 to September 2007.

In the LBC, during the flood period, $P$. bonariensis, $P$. squamoralevis and $L$. anisitsi, all detritivores, were the most abundant species accounting for 61,24 and 14 specimens, respectively. The occurrence of these species as was related to the water turbidity $(44 \pm 13 \mathrm{NTU})$ and conductivity $\left(61.11 \pm 18.21 \mu \mathrm{S}^{\mathrm{s}-1}\right)$, which were higher for all the seasons due to the appearance of organic matter from the adjacent areas, as the river, and consequently providing food for the referred species. H. orthonops and P. maculatus, both omnivorous, were more abundant in the intermediate periods (raising waters and ebb), with 76 and 29 specimens, respectively, considering these two seasons. The occurrence of these species was favoured by the greater water transparency $(126 \pm 5.29 \mathrm{~cm})$ and water depth $(691 \pm 40.42 \mathrm{~cm})$. In the ebb and dry periods, $P$. 
nattereri, A. pantaneiro and P. curviventris were the most abundant species, with 208, 157 and 94 specimens, respectively. With 90 specimens, $P$. ternetzi was the most abundant species in the ebb, using these environments mostly for reproductive purposes. The values of dissolved oxygen $(5.87 \pm 1.03 \mathrm{mg} / \mathrm{l})$, during the dry period, were the most significant relating to the carnivore species, such as $P$. nattereri and $A$. pantaneiro (Figure 7). Considering the two sampling sites, it was found that the species L. anisitsi, $P$. curviventris and $P$. squamoralevis did not occur in the LBC during the high flood period, and the A. pantaneiro was abundant, mainly during the seasons of greater concentration of dissolved oxygen, both in UBC and LBC.

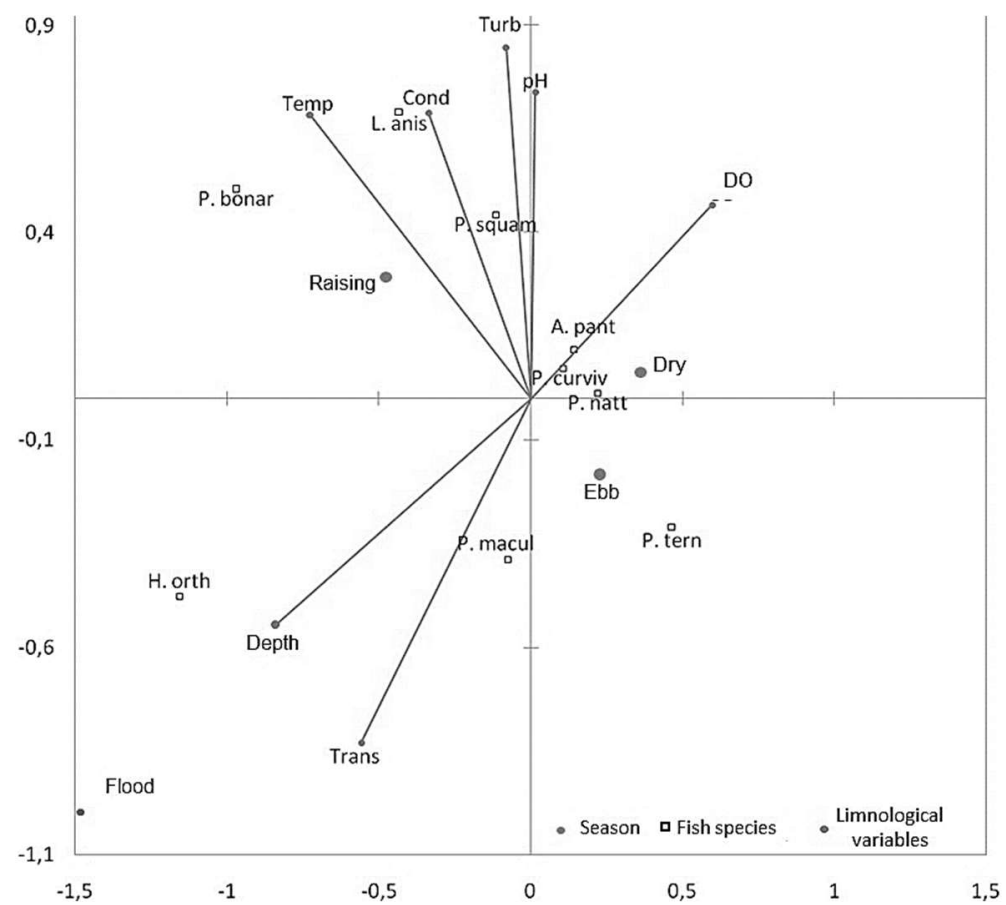

Figure 7: Canonical correspondence analysis ( $F 1$ and F2 $=93.39 \%$ ) of the environmental variables, collected species and sampling sites of the Lower Caiçara oxbow lake (LBC) from September 2005 to September 2007.

\section{DISCUSSION}

This study clearly showed that the biodiversity of fish in oxbow lakes of the Northern Pantanal was determined by the connectivity between the river and the lakes, as well as between the lakes. Although the diversity indices did not show statistical differences, we showed that the diversity increases according to the increment of the water in the system connected to the river, supposing that the river feeds the lake. In contrast, the lake that is not connected to the river did not show this pattern. The limnological variables were also an important factor, first determined by the seasons, and influencing the occurrence of fish species in these oxbow lakes systems.

In our study, the seasons were probably determined by the main river water availability, and, consequently, establishing significant differences between the flood, ebb, dry and rising waters. These physicochemical changes corresponded to the ichthyofauna community structure, corroborating to other researchers who found that there is a narrow relationship between the abiotic and the fish biota present in the water (RESENDE et al., 1996; BARKO et al., 2004). For instance, due to the decrease in dissolved oxygen concentration, there is a limitation on the ichthyofauna distribution or activities (OLIVEIRA et al., 2000), and 
in our study dissolved oxygen was a variable structuring the fish community, mainly during the high waters (flood), when the oxygen concentration reaches the lowest values.

The species diversity is one of the attributes that allow the identification of the communities in a certain environment (MAGURRAN, 2004), which responds to the environment heterogeneity (WINEMILLER et al., 2000) and quality (ESTEVES, 2011). In the Pantanal, the flood pulse of the water promotes an alteration in the amount of available habitat sources, favouring the high diversity of the ichthyofauna species (SILVA et al., 2010). Therefore, floodplains have some of the greatest diversity of species (MOSS, 1995; WINEMILLER, 1996; JUNK, 2000; WELCOMME, 2000). In our study, the Caiçara oxbow lakes system showed values of diversity compared to other studies performed in lakes from Amazon, for instance (FREITAS et al., 2004), but higher than the temperate lakes. Our results also showed higher richness of fish than other rivers from the Mississippi basin (POFF et al., 2001), Swiss rivers (WEBER et al., 2009), and even in streams tributaries of the Paraná river (FLORES et al., 2009).

In these flooding areas, due to the annual seasonal variation, the ichthyofauna developed strategies of occupation for reproduction (OLIVEIRA et al., 2003), feeding (RESENDE et al., 1996; LOWE-MCCONNELL, 1987) and shelter/protection (WELCOMME, 1979). In the Pantanal, the lateral flooding is determinant for the establishment of the referred strategies, promoting increased connectivity between the river and the adjacent basins (JUNK et al., 1989). This can, therefore, change the fish community in the oxbow lakes system, where part of the year is irrigated by the river and other lakes water, but in the other part is disconnected. Other researchers identified that the connectivity between river and side lakes are important to structure the diversity of the fish (PETRY et al., 2003). Species such as L. anisitsi, P. squamoralevis and P. curviventris, detritivore/illiophagous were abundant in the LBC, favoured by the permanent connectivity with the Paraguay River. In the UBC, in turn, only P. curviventris is found in the flood period, with L. anisitsi, $P$. squamoralevis and $P$. curviventris only occurring after the reestablishment of the river and lake connectivity. The connectivity and the greater water transparency played a fundamental role in the ichthyofauna composition in the floodplain in these periods.

During the dry period, with the reduction of available space and decreased availability of food, carnivore species are more numerous (ESCALERA-VAZQUEZ et al., 2017), which was also found in our study, where $A$. pantaneiro and $P$. ternetzi were abundant in the dry and ebb periods in the $L B C$, respectively. In the UBC, the occurrence of $A$. pantaneiro and $P$. ternetzi was also significant, with the latter being the most abundant in this environment. These results were also previously reported by Rezende et al. (1996), in the Southern Pantanal, showing the accretion in the numbers of carnivores during the dry period in lakes.

The restriction of areas and/or the few connectivity points favour the occurrence of species such as P. nattereri and A. pantaneiro, which may adopt prowling or active pursuit of prey (SAZIMA et al., 1982), ensuring their survival and abundance. In the flood season, these species were less abundant both in the UBC and LBC, which is probably because of the dilution caused by the increase in the flooded area, reestablishing the river and lake connectivity (BONETTO, 1993), consequently causing the homogenization of the entire system. The connectivity also reflected in the selectivity of the gill nets in our study. The selectivity 
represented $90 \%$ of all the specimens sampled in the lake disconnected to the river during part of the year, contrasting the fact that these devices may have taken only half of the specimens in the site connected to the river the whole year. Although the abundance of fish was overestimated due to the selectivity of the gillnets, the estimated diversity was less than $1 \%$ lower than the fish caught in the lakes. The discrepancy was higher during the flood (4\%), yet close to the total. Although the gill nets have been widely used and established for the capture of some species (NAKATANI et al., 1991; GRAY et al., 2000; PESSERL, 2007), in the Pantanal the gillnets may not reflect the entire community of fish in water propitious to raise and the expand laterally. Due to the high spatial complexity and habitat heterogeneity, the fish may escape the nets by using the shore (with high density and abundance of macrophytes) or the flooded area as a shelter, where it is impossible to catch using these devices due to the access and depth. However, the gill nets may increment the efforts to complete the samples made with other displays.

ACKNOWLEDGEMENTS: we thank the Universidade do Estado de Mato Grosso (UNEMAT) and the Fundação de Amparo à Pesquisa de Mato Grosso (FAPEMAT) for offering their facilities, and the Research Center of Pantanal (CPP/MCT) for the financial support.

\section{REFERENCES}

ABDO, M. S. A.; DA SILVA, C. J.. Limnological characteristics of the water bodies of the Corutuba Nesting Site in Brazil's Pantanal. Acta Limnologica Brasiliensia, v.16, n.4, p.359368, 2004

ALHO, C. J. R.. Biodiversity of the Pantanal: response to seasonal flooding regime and to environmental degradation. Brazilian Journal of Biology, v.68, n.4, p.957-966, 2008. DOI: http://dx.doi.org/10.1590/S1519-69842008000500005

BARKO, V. A.; HERZOG, D. P.; HRABIK, R. A.; SCHEIBE, J. S.. Relationship among fish assemblages and main-channelborder physical habitats in the unimpounded upper Mississippi River. Transactions of the American Fisheries Society, v.133, n.2, p.371-384, 2004. DOI: https://doi.org/10.1577/02-103

BONETTO, A. A.; CANON VERON, M.; ROLDAN, D.. Nuevos aportes al conocimiento de las migraciones de peces en el Río Paraná. ECOSUR, v.8, n.16, p.29-40, 1981.

BONETTO, A. A.. Structure and functioning of large river floodplains of neotropical America: the Parana-Paraguay system. In: GOPAL, B.; HILLBRICHT-ILKOWSKA, A.; WETZEL, R. G.. Wetlands and ecotones: studies on land-water Interactions. New Delhi: National Institute of Ecology, 1993. p.123-138.

BRITSKI, H. A.; SILIMOM, K. Z. S.; LOPES, B. S.. Peixes do Pantanal: Manual de Identificação. Brasília: Embrapa. 1999.

CARVALHO, E. D.; MARCUS, L. R.; FORESTI, F.; SILVA, V. F. B.. Fish assemblage attributes in a small oxbow lake (Upper Parana River Basin, Sao Paulo State, Brazil): species composition, diversity and ontogenetic stage. Acta Limnologica Brasiliensia, v.17, n.1, p.45-56, 2005.
COSTA, I. D.; FREITAS, C. E. C.. Factors determining the structure of fish assemblages in an Amazonian river near to oil and gas exploration areas in the Amazon basin (Brazil): establishing the baseline for environmental evaluation. Zoologia, Curitiba, v.32, n.5, p.351-359, 2015. DOI: http://dx.doi.org/10.1590/S1984-46702015000500004

ESCALERA-VÁZQUEZ, L. H.; CALDERÓN-CORTÉS, N.; ZAMBRANO-GONZÁLEZ, L.. Fish population responses to hydrological variation in a seasonal wetland in southeast México. Neotropical Ichthyology, v.15, n.2, 2017. DOI: http://dx.doi.org/10.1590/1982-0224-20160129

ESTEVES, F. A.. Fundamentos de Limnologia. 3 ed. Rio de Janeiro: Interciência, 2011.

FLORES, S.; ARAYA, P. R.; HIRT, L. M.. Fish diversity and community structure in a tributary stream of the Paraná River. Acta Limnologica Brasiliensia, v.21, n.1, p.57-66, 2009.

FREITAS, C. E. C.; GARCEZ, R. C. S.. Fish communities of natural channels between floodplain lakes and SolimoesAmazonas River (Amazon-Brazil). Acta Limnologica Brasiliensia, v.16, n.3, p.273-280, 2004

FERNÁNDEZ-OSUNA, M. A.; SCARABOTTI, P. A.. Phenotypic plasticity associated to environmental hypoxia in the neotropical serrasalmid Piaractus mesopotamicus (Holmberg, 1887) (Characiformes:

Serrasalmidae). Neotropical ichthyology, Maringá, v.14, n.2. DOI: http://dx.doi.org/10.1590/1982-0224-20150187

GLINSKA-LEWCZUK, K.; BURANDT, P.; KUJAWA, R.; KOBUS, S.; OBOLEWSKI, C.; DUNALSKA J.; GRABOWSKA, M.; LEW, 
S.; AND CHORMANSKI, J.. Environmental Factors Structuring Fish Communities in Floodplain Lakes of the Undisturbed System of the Biebrza River. Water, v.8, n.4, p.146, 2016. DOI: https://doi.org/10.3390/w8040146

GRAY, C. A.; LARSEN, R. B.; KENNELLY, S. J.. Use of transparent netting to improve size selectivity and reduce bycatch in fish seine nets. Fisheries Research, v.45, n.2, p.155-166, 2000. DOI: https://doi.org/10.1016/S01657836(99)00111-3

HOLT, S. J.. A method for determining gear selectivity and its application. ICNAF Spec. Publ., v.5, p.106-115, 1963.

HOVGÅRD, H.; LASSEN, H.. Manual on estimation of selectivity for gillnets and longline gears in abundance surveys. Rome: FAO Fisheries Technical Paper, 2000.

JUNK, W. J.. The central Amazon river floodplain: concepts for the sustainable use of its resources. In: JUNK, W. J.; OHLY, J. J.; PIEDADE, M. T. F.; SOARES, M. G. M.. The central Amazon floodplain: actual use and options for a sustainable management. The Netherlands: Backhauls Publishers. 2000. p.75-94.

JUNK, W. J.; BAYLEY, P. B.; SPARKES, R. S.. The flood pulse concept in river floodplain systems. In: DODGE, D. P.. Proceedings of the International Large River Symposium. Canadian Publication Fisheries and Aquatic Science. 1989, p.110-127.

LOWE-MCCONNELL, R. H.. Ecological studies in tropical fish communities. Great Britain: University Press, 1987.

MAGURRAN, A. E.. Measuring biological diversity. Oxford: Blackwell Publishing Company, 2004.

MORAES, E. C.; PEREIRA, G.; CARDOZO, F. D. S.. Avaliação da precipitação e sua influência sobre as áreas inundadas no Pantanal.. In: SIMPÓSIO BRASILEIRO DE SENSORIAMENTO REMOTO, 11. Anais. Foz do Iguaçu: INPE, 2013.

MOSS, B.. Ecology of fresh waters: man and medium. 2 ed. London: Blackwell Science. 1995.

NAKATANI, K.; GOMES, L. C.; LATINI, J. D.. Seletividade em redes de espera para captura de Trachydoras paraguayensis (Osteichthyes, Siluriformes), no reservatório de Itaipú e áreas de sua influência. Revista UNIMAR, Maringá, v.13, n.2, p.327-338, 1991.

OLIVEIRA, A. K. D.; GARAVELLO, J. C.. Fish assemblage composition in a tributary of the Mogi Guaçu river basin, southeastern Brazil. Iheringia. Série Zoologia, Porto Alegre, v.93, n.2, p.127-138, 2003. DOI: http://dx.doi.org/10.1590/S0073-47212003000200002

OLIVEIRA, E. F.; GOULART, E.. Distribuição espacial de peixes em ambientes lênticos: interação de fatores. Acta Scientiarum, v.22, n.2, p.445-453, 2000.

PESSERL, B. H.. Seletividade de captura de redes de emalhe em um ambiente de Gamboa. Dissertation (Master in Biological Sciences) - Universidade Federal do Paraná, Curitiba, 2007.

PetRY, A. C.; AgOStinhO, A. A.; GOMES, L. C.. Fish assemblages of tropical floodplain lagoons: exploring the role of connectivity in a dry year. Neotropical Ichthyology, Porto Alegre, v.1, n.2, p.111-119, 2003. Dol: http://dx.doi.org/10.1590/S1679-62252003000200005

POFF, L. N.; ANGERMEIER, P. L.; COOPER, P. S.; LAKE, P. S.; KURT, D. F.; WINEMILLER, K. O.; LEAL, A. K. M.; OSWOOD, M. W.; REYNOLDS, J.; RAHEL, F. J.. Fish Diversity in Streams and Rivers. In: CHAPIN, F. S.; SALA, O. E.; HUBERSANNWALD, E.. Global Biodiversity in a Changing Environment. Ecological Studies (Analysis and Synthesis). New York: Springer, 2001. p.315-349.

POTT, V. J.; POTT, A.; LIMA, L. C. P.; MOREIRA, S. N.; OLIVEIRA, A. K. M.. Aquatic macrophyte diversity of the Pantanal wetland and upper basin. Brazilian Journal of Biology, São Carlos, v.71, n.1, p.255-263, 2011. DOI: http://dx.doi.org/10.1590/S1519-69842011000200004

RESENDE, E. K.; PEREIRA, R. A. C.; ALMEIDA, V. L. L.; SILVA, A. G.. Alimentação de peixes carnívoros da planície inundável do rio Miranda, Pantanal, Mato Grosso do Sul, Brasil. Corumbá: EMBRAPA Pantanal, 1996.

SAZIMA, I.; MACHADO, F. A.. Hábitos e comportamento de Roeboides prognathus, um peixe lepidofágico (Osteichthyes, Characoidei). Boletim Zoologia e Biologia Marinha, São Paulo, v.7, p.37-56, 1982.

SILVA, H. P.; PETRY, A. C.; SILVA, C. J.. Fish communities of the Pantanal wetland in Brazil: evaluating the effects of the upper Paraguay river flood pulse on baía Caiçara fish fauna. Aquatic ecology, v.44, n.1, p.275-288, 2010. DOI: https://doi.org/10.1007/s10452-009-9289-9

SPARRE, P.; VENEMA, S. C.. Introdução à avaliação de mananciais de peixes tropicais. Roma: FAO Documento Técnico sobre as pescas, 1997.

TAKAHASHI, E. L. H.; ROSA, F. R. T.; LANGEANI, F.; NAKAGHI, L. S. O.. Spatial and seasonal patterns in fish assemblage in Córrego Rico, upper Paraná River basin. Neotropical Ichthyology, Porto Alegre, v.11, n.1, p.143-152, 2013. DOI: http://dx.doi.org/10.1590/S167962252013000100017

TALBOT, C. J.; BENNETT, E. M.; CASSELL, K.; HANES, D. M.; MINOR, E. C.; PAERL, H.; RAYMOND, P. A.; VARGAS, R.; VIDON, P. G.; WOLLHEIM, W.; XENOPOULOS, M. A.. The impact of flooding on aquatic ecosystem services. Biogeochemistry, v.141, n.3, p.439-461, 2018. DOI: https://doi.org/10.1007/s10533-018-0449-7

THOMAZ, S. M.; BINI, L. M.; BOZELLI, R. L.. Floods increase similarity among aquatic habitats in river-floodplain systems. Hydrobiologia, v.579, n.1, p.1, 2007. DOI: http://doi.org/10.1007/s10750-006-0285-y

VAZZOLER, A. E. A. M.. Biologia da reprodução de peixes teleósteos: teoria e prática. Maringá: Eduem, 1996.

WANTZEN, K. M.; JUNK, W. J.; ROTHHAUPT, K. O.. An extension of the floodpulse concept (FPC) for lakes. In: WANTZEN, K. M.; ROTHHAUPT, K. O.; MÖRTL, M.; CANTONATI, M.; TÓTH, L. G.; FISCHER, P.. Ecological Effects of Water-Level Fluctuations in Lakes. Dordrecht: Springer, 2008. p.151-170. 
WEBER, C.; SCHAGER, E.; PETER, A.. Habitat diversity and fish assemblage structure in local river widenings: a case study on a swiss river. River Research and Applications, v.25, n.6, p.687-701, 2009. DOI:

https://doi.org/10.1002/rra.1176

WELCOMME, R. L.. Fish biodiversity in floodplains and their associated rivers. In: GOPAL, B.; JUNK, W. J.; DAVIS, J. A.. Biodiversity in wetlands: assessment, function and conservation. Netherlands: Backhuys publishers, 2000. p.61-87.

WELCOMME, R. L.. Fisheries ecology of Floodplain Rivers. London: Longman, 1979.
WINEMILLER, K. O.. Development of dermal lip protuberances for aquatic surface respiration in South American characid fishes. Copeia, n.2, p.382-390, 1989.

WINEMILLER, K. O.. Dynamic diversity in fish assemblages of tropical rivers. In: CODY, M. L.; SMALLWOOD, J. A.. LongTerm studies of vertebrate communities. Orlando: Academic Press, 1996. p.99-134.

WINEMILLER, K. O.; TARIM, S.; SHORMANN, D.; COTNER, J. B.. Fish assemblage structure in relation to environmental variation among Brazos River oxbow lakes. Transactions of the American Fisheries Society, v.129, n.2, p.451-468, 2000.

A CBPC - Companhia Brasileira de Produção Científica (CNPJ: 11.221.422/0001-03) detém os direitos materiais desta publicação. Os direitos referem-se à publicação do trabalho em qualquer parte do mundo, incluindo os direitos às renovações, expansões e disseminações da contribuição, bem como outros direitos subsidiários. Todos os trabalhos publicados eletronicamente poderão posteriormente ser publicados em coletâneas impressas sob coordenação da Sustenere Publishing, da Companhia Brasileira de Produção Científica e seus parceiros autorizados. Os (as) autores (as) preservam os direitos autorais, mas não têm permissão para a publicação da contribuição em outro meio, impresso ou digital, em português ou em tradução. 